УДК 661.183.2, 620.181.4

\title{
ИЗУЧЕНИЕ ТЕРМОПРЕВРАЩЕНИЯ БЕТУЛИНА В УСЛОВИЯХ ЩЕЛОЧНОЙ АКТИВАЦИИ
}

\author{
(ㄱ Н.М. Микова ${ }^{1 *}$ Н.В. Чесноков ${ }^{1,2}$, Е.В. Мазурова ${ }^{1}$, Н.И. Павленко ${ }^{I}$, Н.М. Иванченко \\ ${ }^{1}$ Институт химии и химической технологии СО РАН, Академгородок, 50-24, \\ Красноярск, 660036 (Россия), e-mail: nm@icct.ru \\ ${ }^{2}$ Красноярский научный чентр СО РАН, Академгородок, 50, Красноярск, \\ 660036 (Россия)
}

Изучена карбонизация бетулина (бетулинола) как индивидуального углеродистого предшественника в интервале температур $400-800^{\circ} \mathrm{C}$ в присутствии КОН. Методами ДТА-анализа и ИК-спектроскопии определено влияние КОН на основные изменения структурного и химического составов бетулина, которые он претерпевает при температуре $400-500{ }^{\circ} \mathrm{C}$. Методами сканирующей электронной микроскопии и БЭТ-анализа показано, что при температурах 600 $800{ }^{\circ} \mathrm{C}$ КОН способствует формированию развитой удельной поверхности $\left(\mathrm{S}_{\text {Бэт }} 1350-2100 \mathrm{~m}^{2} / \Gamma\right)$ и оказывает наибольшее влияние на текстурные и адсорбционные свойства получаемых пористых углеродных адсорбентов. Установлено, что активированием КОН бетулина при $800{ }^{\circ} \mathrm{C}$ возможно получать микропористые углеродные материалы с размером пор 1,92 нм и удельной поверхностью микропор $1275 \mathrm{~m}^{2} / \Gamma$. Предложено использование бетулина в качестве регулятора пористости углеродных носителей из древесины березы.

Ключевые слова: бетулин, щелочная активация, карбонизация, пористость, углеродный адсорбент, морфология поверхности.

\section{Введение}

Разработка безотходных и ресурсосберегающих технологий переработки древесины березы предполагает более полное вовлечение всех частей дерева и, в частности, наружного слоя березовой коры - бересты в процесс комплексной переработки. Кора березы является ценным вторичным сырьем для получения материалов с практически важными свойствами, преимущественно, на основе главных компонентов коры - луба и бересты [1, 2].

Наиболее распространенные пути химической переработки биомассы коры предполагают экстрактивное выделение пентациклических тритерпеноидов: бетулина, лупеола, суберина и др. Бетулин (бетулинол) - самое распространенное органическое соединение и самый изученный компонент бересты березы, извлекаемый путем экстракции рядом органических растворителей, служащий исходным продуктом для синтеза на его основе многих биологически активных веществ [3, 4]. Многочисленные исследования проведены по изучению бетулина в качестве природного предшественника в производстве канифольных лаков и защитных покрытий с высокими

Микова Надежда Михайловна - старший научный сотрудник, кандидат химических наук, e-mail: nm@icct.ru Чесноков Николай Васильевич - временно исполняющий обязанности директора, доктор химических наук, e-mail: cnv@icct.ru

Мазурова Елена Валентиновна - научный сотрудник, e-mail: kargin@icct.ru

Павленко Нина Ивановна - ведущий научный сотрудник, кандидат химических наук, e-mail: pni@icct.ru Иванченко Наталья Михайловна - старший научный сотрудник, кандидат химических наук, e-mail: inm@icct.ru водостойкостью, инертностью к химическим и биологическим воздействиям [5].

Учитывая реакционную способность бетулина и его производных к разнообразным химическим превращениям, можно полагать, что полученные вещества могут не только представлять потенциальный практический интерес в медицине и фармакологии, но и иметь широкие перспективы применения для расширения ассортимента полу-

\footnotetext{
* Автор, с которым следует вести переписку.
} 
чаемых химической переработкой востребованных продуктов различного функционального назначения, в том числе сорбентов и углеродных материалов.

Использование относительно недорогих углеродных материалов (УМ) с оптимальным размером пор, подходящим для очистки и разделения газообразных систем, является перспективным направлением [6]. Одним из возможных путей регулирования текстуры углеродных адсорбентов (УА) является нанесение в контролируемых условиях органического вещества или углеводорода в качестве модификатора пористости уже готового углеродного носителя, обладающего определенным набором пор [7].

Способ модификации пор карбонизованного угля определенной пористой структуры природным химическим соединением - бетулином и дополнительной щелочной активацией был использован нами ранее при изучении подхода к формированию однородной микротекстуры при приготовлении УА из натурального углеродистого предшественника - древесины березы Betula birch (ДБ) [8]. За счет регулирования реакционной способности карбонизованных при 500-800 ${ }^{\circ} \mathrm{C}$ предшественников из ДБ, модификации пор существующего размера бетулином, взятым в количестве $25 \%$ масс. с целью создания углеродной композиции, и затем последующей активации КОН при $600-800{ }^{\circ} \mathrm{C}$ получены модифицированные УА с контролируемой способностью для селективной адсорбции и разделения смеси газов $\mathrm{H}_{2}(\mathrm{He})-\mathrm{CH}_{4}$. Как установлено проведенными исследованиями, действие органического модификатора бетулина в создании углеродной композиции на поверхности углеродного носителя из ДБ эффективно в определенном температурном интервале $\left(400-450{ }^{\circ} \mathrm{C}\right)$, но характер этого влияния оставался не вполне понятным. С целью выяснения наиболее подходящих условий для проявления пороформирующего действия бетулина нами проведены модельные эксперименты по изучению его термохимических превращений как индивидуального углеродистого предшественника в присутствии КОН при различных температурах.

Цель настоящей работы - исследование особенностей поведения модификатора пористости - бетулина в процессе формирования пористой структуры углеродных сорбентов в присутствии КОН.

\section{Экспериментальная часть}

В качестве объекта исследования использовали порошкообразный бетулин (продукт экстракции бересты березы), выделенный с чистотой 96-98\% после перекристаллизации из этанола, согласно методике [9]. Элементный состав, \%: С - 81,7; Н - 11,5.

Получение углеродных продуктов методом термохимической активации бетулина гидроксидом калия в массовом отношении $1: 3$ осуществляли в интервале температур $400-800{ }^{\circ} \mathrm{C}$ в соответствии с методом, описанным в [10].

Сорбционную способность углеродных адсорбентов к поглощению паров бензола оценивали в стационарных условиях равновесного заполнения пор при комнатной температуре.

Характеристики пористости УМ (удельной поверхности, общего объема пор и объема микропор) получены из анализа изотерм адсорбции азота, снятых при 77 К после предварительной тренировки образцов при $300{ }^{\circ} \mathrm{C}$ и остаточном давлении 0,001 мм рт. ст. на установке ASAP 2420 Micrometrics в диапазоне относительных давлений $\mathrm{P} / \mathrm{P}_{0}$ от 0,005 до 0,995 .

Регистрация ИК-спектров в области длин волн 400-4000 $\mathrm{cm}^{-1}$ проведена на ИК-Фурье спектрометре Vector 22 в (разрешение $2 \mathrm{~cm}^{-1}, \mathrm{SC}=50$ ). Обработка спектральной информации проведена по программе OPUS.3, версия 2.2. Образцы для съемки спектров готовились в матрице бромистого калия при фиксированных навесках вещества и матрицы.

Морфологические исследования поверхности и рентгеноспектральный анализ (РСА) качественного и полуколичественного химических составов углеродных образцов проведены на сканирующем электронном микроскопе TM-3000 Hitachi HТ (Япония), оснащенном энергодисперсионным рентгеноспектральным анализатором Quantax 70 (Bruker). Обработку рентгеновских спектров излучения элементов проводили с использованием программного обеспечения спектрометра. Количественное содержание нормировано к $100 \%$.

Термогравиметрическое изучение исходного бетулина выполнено с использованием анализатора

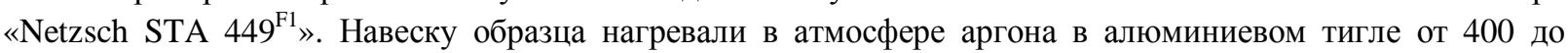
$700{ }^{\circ} \mathrm{C}$ при скорости нагрева $5{ }^{\circ} \mathrm{C} /$ мин.

\section{Обсуждение результатов}

Проведенными исследованиями выявлена принципиальная возможность образования пористой углеродной структуры в продуктах термопревращения органического вещества - бетулина под действием щелочного реагента. Результаты по изучению параметров пористости и сорбционной способности к по- 
глощению паров воды и бензола образцов, получаемых активацией КОН бетулина в соотношении $3: 1$, представлены в таблице 1.

Как показывают данные таблице $1, \mathrm{KOH}$ наиболее эффективно развивает поры в температурном интервале $600-800{ }^{\circ} \mathrm{C}$. Однако при относительно невысокой температуре $400{ }^{\circ} \mathrm{C}$ продукт щелочного воздействия отличается незначительной $\mathrm{S}_{\text {Бэт }}\left(156 \mathrm{~m}^{2} / \Gamma\right)$ и слабо развитым пористым объемом. При этом образец характеризуется самым высоким показателем поглощения бензола $(\sim 1$ г/г) и низким - паров воды $(0,06$ г/г), что по аналогии с исходным бетулином может являться следствием присутствия большого количества малополярных алкильных фрагментов и нейтральных группировок. Образец бетулин + КОН (400), строго говоря, не является углеродным продуктом, а, скорее, промежуточным производным термохимического превращения (пиролизатом) и, видимо, сохраняет в своем составе достаточное количество бетулинсодержащих компонентов, поэтому имеет, подобно бетулину, большее сродство к растворителям средней полярности, чем к малополярным растворителям [11].

Изучение превращения бетулина при температуре $400{ }^{\circ} \mathrm{C}$, выполненное в отсутствие КОН, показало, что вещество в виде расплава подвергается постепенному пирогенетическому разложению с выделением газообразных фракций и образованием с низким выходом ( 7\% вес.) пленкообразного продукта пиролиза. Результаты сравнительного изучения методом сканирующей электронной микроскопии (СЭМ) исходного бетулина (А) и продукта его превращения при температуре $400{ }^{\circ} \mathrm{C}($ (Б) представлены на рисунке 1.

Как видно на рисунке $1, A$, исходное соединение находится в форме крупных агрегатов частиц, состоящих из относительно упорядоченных кристаллитов со средним размером 3-10 мкм. Термообработка бетулина при $400{ }^{\circ} \mathrm{C}$, сопровождающаяся частичной возгонкой и пластической деформацией вещества, приводит к образованию слабопористого продукта, который, согласно данным СЭМ, выглядит подобно полимерной пленке с наплавленными частицами бетулина (рис. 1,5 ). Поры внутри такого пленкообразного материала экстремально малы вследствие затрудненного выхода газов, образующихся при плавлении образца.

Проведенный термогравиметрический анализ процесса терморазложения бетулина обнаруживает на кривой ДСК (рис. 2, кривая 2) появление эндотермического пика с величиной $-0,624 \mathrm{мBT} / \mathrm{M \Gamma}$ при $250,2{ }^{\circ} \mathrm{C}$, по всей вероятности, обусловленого плавлением бетулина, потеря массы на этом этапе не превышала $0,7 \%$ и связана с удалением адсорбированных примесей [9].

Таблица 1. Зависимость удельной поверхности $\left(\mathrm{S}_{\text {Бэт }}\right)$, пористого объема $\left(\mathrm{V}_{\text {пор }}\right)$ и сорбционных свойств образцов, полученных из бетулина при различных температурах активирования $\mathrm{KOH}$

\begin{tabular}{c|c|c|c|c}
\hline Образец & $\mathrm{S}_{\text {Бэт, } \mathrm{M}^{2} / \Gamma}$ & $\mathrm{V}_{\text {пор }}, \mathrm{cm}^{3} / \Gamma$ & Сорбция $\mathrm{H}_{2} \mathrm{O}, \Gamma / \Gamma$ & Сорбция $\mathrm{C}_{6} \mathrm{H}_{6}, \Gamma / \Gamma$ \\
\hline Бетулин, исх. (Б) & - & 0,005 & 0,01 & 0,55 \\
Бетулин + КОН (400) & 156 & 0,10 & 0,06 & 0,97 \\
Бетулин + КОН (500) & 465 & 0,22 & 0,22 & 0,25 \\
Бетулин + КОН (600) & 680 & 0,39 & 0,35 & 0,38 \\
Бетулин + КОН (700) & 911 & 0,56 & 0,54 & 0,50 \\
Бетулин + КОН (800) & 1350 & 0,65 & 0,53 & 0,56 \\
\hline
\end{tabular}

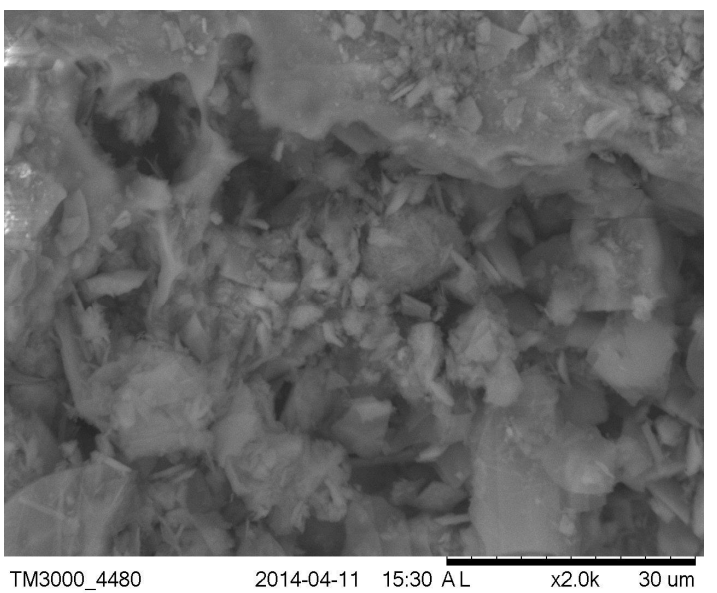

$A$

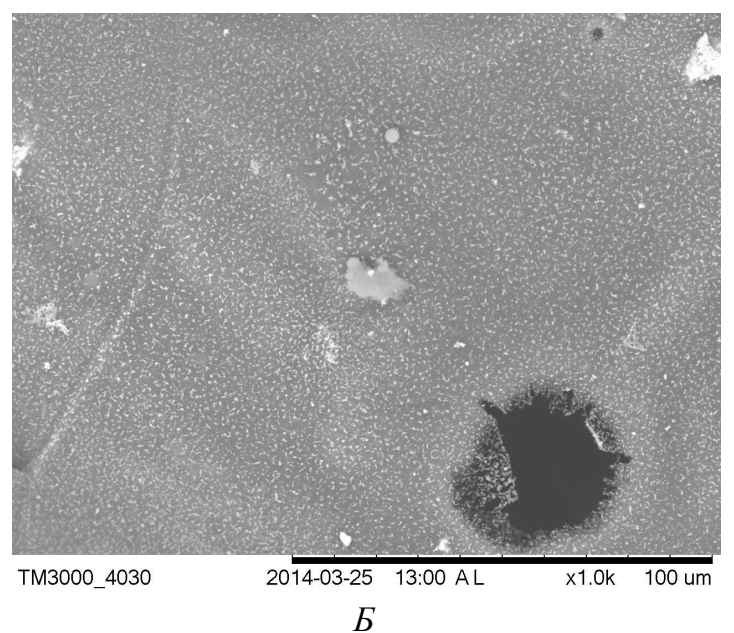

Рис. 1. Микрофотографии образцов бетулина: А - исходного; Б - бетулина после термообработки при $400{ }^{\circ} \mathrm{C}$ (бетулин-400) 


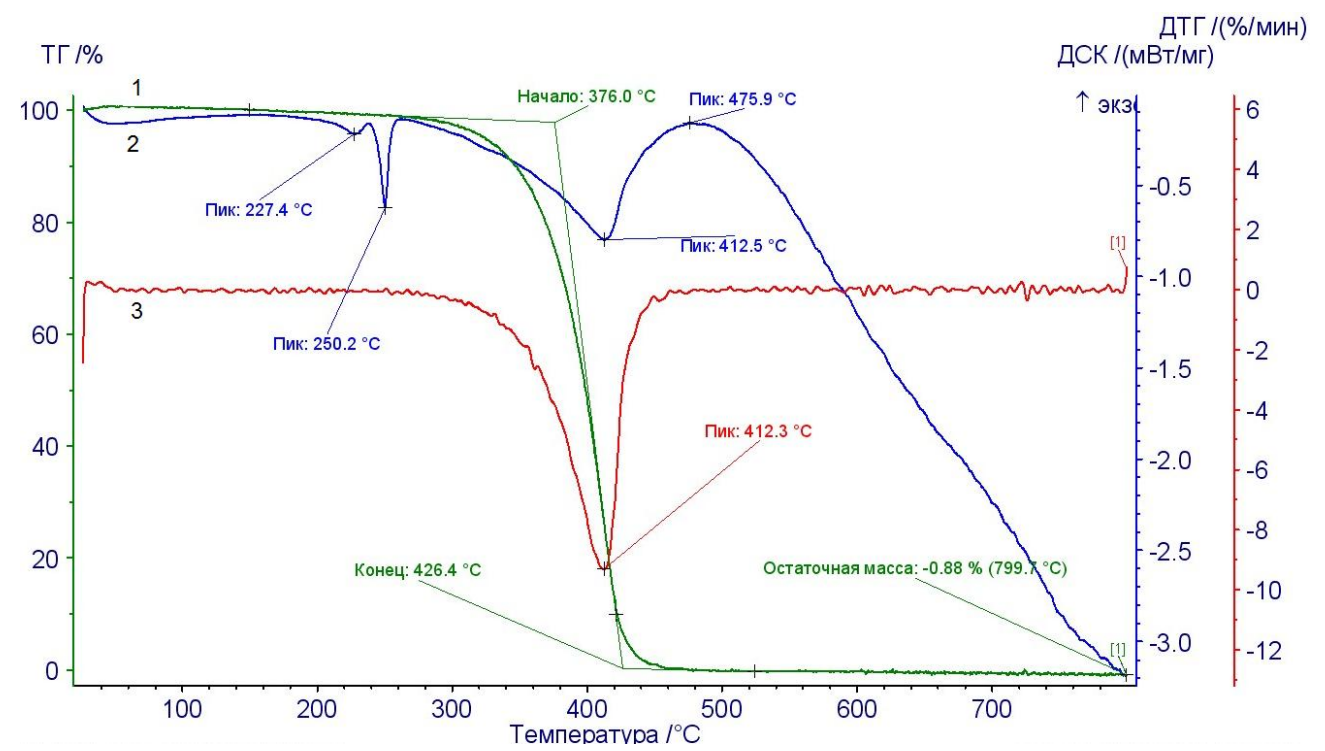

Рис. 2. ТГ/ДТГ термогравиметрические кривые потери массы бетулина от температуры

На профиле кривых ТГ/ДТГ (рис. 2, кривые 1 и 3) выделяется основная стадия потери массы вещества в интервале температур $350-450{ }^{\circ} \mathrm{C}$. Начало процесса разложения со скоростью $0,05 \% /$ мин зарегистрировано при $363{ }^{\circ} \mathrm{C}$. Процесс достигает максимальной скорости разложения 9,31\%/мин с пиком при $412,5^{\circ} \mathrm{C}$, при этом общая убыль массы составила 75\%. Замедление скорости потери массы до значения 6,77\% /мин с остаточной массой $6,88 \%$ отмечалось при $426,4{ }^{\circ} \mathrm{C}$, последовательно стремясь к минимуму вплоть до температуры $475^{\circ} \mathrm{C}$.

Соответствующему температурному интервалу термопревращения образца на кривой ДСК (рис. 2, кривая 2) отвечает эндотермический пик с величиной эндоэффекта $-0,798$ мВт/мг, вероятно, связанный с возгонкой бетулина и структурной перестройкой расплавленной массы исследуемого вещества.

Анализ полученных кривых показывает, что процесс термического превращения индивидуального бетулина наиболее интенсивно происходит при температуре $400 \pm 25{ }^{\circ} \mathrm{C}$.

Термохимическое превращение бетулина при $400{ }^{\circ} \mathrm{C}$ в присутствии щелочи отличается более высоким выходом твердого остатка ( 50\% вес.), по-видимому, КОН препятствует возгонке бетулина, а также, возможно, способствует удерживанию С-содержащих летучих фрагментов деструкции и, следовательно, способствует сохранению углерода и повышению выхода конечного УМ [12]. Изменение содержания углерода и кислорода в продуктах превращения бетулина (Б) при его нагревании от 400 до $800{ }^{\circ} \mathrm{C}$, согласно данным РСА, приведено в таблице 2.

Добавка активирующего агента способствует не только последовательному возрастанию содержания углерода в термоактивированных образцах, но также и процессам деполимеризации и порообразования. Данные СЭМ, приведенные на рисунке 3, подтверждают это предположение и свидетельствуют о формировании пор размером около 1 мкм в активированном продукте бетулин + КОН (400), обладающем пористой губчатой структурой (рис. 3, А) в отличие от образца бетулин-400 (рис. 1, Б).

Исходя из анализа микрофотографий и результатов изучения пористой структуры образцов, можно заключить, что присутствие КОН модифицирует поведение бетулина в процессе термодеструкции. Вследствие значительной молекулярной массы природного вещества и наличия полярных групп их активное взаимодействие начинается с повышением температуры $\left(\sim 400{ }^{\circ} \mathrm{C}\right)$, когда оба компонента присутствуют в форме расплавов, и большая площадь поверхности реагирующих веществ способствует их лучшему контакту. Присутствие катионов К оказывает значительное влияние на направление термохимического разложения, в частности на образование газообразных веществ и выход угля $[12,13]$.

Таблица 2. Элементный анализ (C, О, ат.\%) углеродных образцов, полученных активацией КОН бетулина (Б) при температуре $400-800{ }^{\circ} \mathrm{C}$

\begin{tabular}{c|c|c|c|c|c|c}
\hline \multirow{2}{*}{ Элемент } & \multicolumn{7}{|c}{ Образец } \\
\cline { 2 - 7 } & Б-400 & Б + КОН (400) & Б + КОН (500) & Б + КОН (600) & Б + КОН (700) & Б + КОН (800) \\
\hline углерод & 75,58 & 76,18 & 77,79 & 81,21 & 83,31 & 90,61 \\
кислород & 8,32 & 16,82 & 14,17 & 10,07 & 9,22 & 8,26 \\
\hline
\end{tabular}




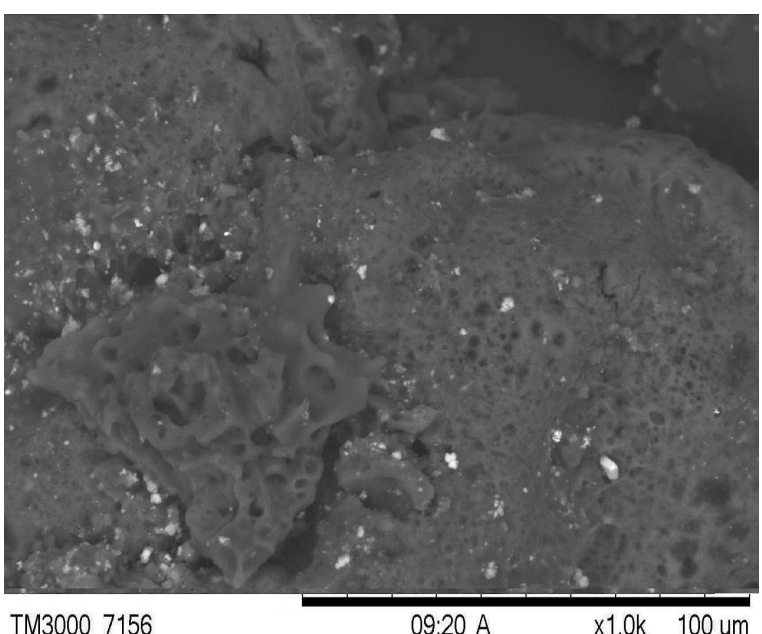

TM3000 7156

А - бетулин + КОН (400)

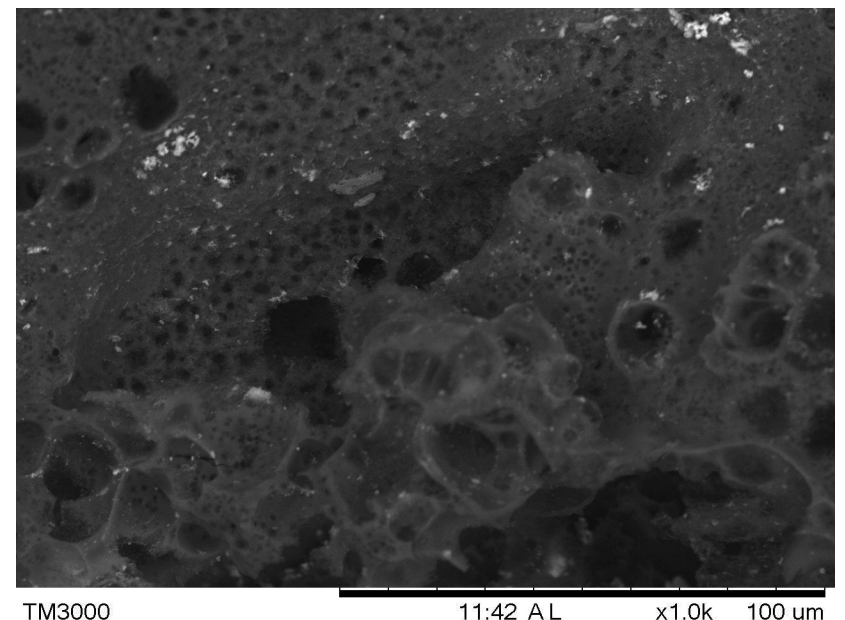

Б - бетулин + КОН (800)

Рис. 3. Микрофотографии образцов бетулина, активированного КОН в массовом соотношении $1: 3$ при температуре 400 и $800{ }^{\circ} \mathrm{C}$

При температурах, более высоких, чем $400{ }^{\circ} \mathrm{C}$, по мере углубления процесса термической деструкции бетулина и вовлечения вторичных продуктов разложения в активационный процесс происходит увеличение значений удельной поверхности, пористого объема и усиление микропористости УМ с наблюдаемым, в частности, для Бетулин + КОН (800), размером пор около 0,3-0,6 мкм (рис. 3Б). Модифицирующее участие КОН в процессе карбонизации бетулина в интервале температур 400-800 ㄷ выражается в формировании в активированных образцах высокопористой углеродной структуры, возможно, за счет протекания реакций газификации углерода и интеркалирования частиц К, способствующих развитию пористой структуры $[13,14]$.

Характер поглощения паров воды и бензола в активированных углеродных образцах из бетулина находится в соответствии с изменением текстурных параметров и указывает на развитие микропористости. Лучшие показатели сорбции бензола демонстрируют образцы бетулина, активированного КОН при температуре $700-800{ }^{\circ} \mathrm{C}$ (табл. 3).

Изучение изотерм адсорбции азота при 77 К на активированных углеродных образцах бетулина показало, что форма изотерм является присущей микропористым объектам [8]. Однако углеродные образцы, полученные активацией при 400-500 ${ }^{\circ} \mathrm{C}$, имеют слабо развитую пористую структуру и широкий интервал распределения пор со средним значением около 2,63 нм.

Как видно из сравнения приведенных в таблице 3 характеристик пористой структуры углеродных образцов из бетулина, активированного КОН при 400 и $800{ }^{\circ} \mathrm{C}$, средний размер микропор у образца бетулин + КОН (800), обладающего относительно узким распределением пор по размерам, составляет 1,92 нм, а удельная поверхность микропор достигает $1275 \mathrm{~m}^{2} / г$.

Сравнение ИК-спектров образцов бетулина, термообработанного при $400{ }^{\circ} \mathrm{C}$ в присутствии КОН и без него (рис. 4, кривые 1 и 2), выявило подобие и различие их спектральной картины. Спектры обоих образцов демонстрируют в своем составе широкую и интенсивную полосу поглощения (п.п.) с максимумом при $3426 \mathrm{~cm}^{-1}$, характеризующую валентные колебания О-Н связей $\left(v_{\mathrm{O}-\mathrm{H}}\right)$ спиртов и фенолов, участвующих в сильных межмолекулярных взаимодействиях. Наличие интенсивных п.п. в спектре образца бетулин-400 (рис. 4, кривая 1) при 1709 см$^{-1}$ указывает на присутствие карбонильных/карбоксильных C=O групп, а при $1624 \mathrm{~cm}^{-1}$ - ароматических структур с ненасыщенными $\mathrm{C}=\mathrm{C}$ связями, возможно, включенными в систему сопряжения [15].

Таблица 3. Характеристики пористости углеродных образцов из бетулина, активированного КОН при 400 и $800{ }^{\circ} \mathrm{C}$

\begin{tabular}{c|c|c|c|c|c}
\hline Углеродный образец & $\mathrm{S}_{\text {Бэт, }} \mathrm{m}^{2} / \Gamma$ & $\mathrm{S}$ микро, $\mathrm{m}^{2} / \Gamma$ & Vобщ., $\mathrm{cm}^{3} / \Gamma$ & $\mathrm{W}$ микро, $\mathrm{cm}^{3} / \Gamma$ & Диаметр пор, нм \\
\hline Бетулин + КОН (400) & 156 & 128 & 0,09 & 0,06 & 2,63 \\
Бетулин + КОН (800) & 1350 & 1275 & 0,65 & 0,55 & 1,92 \\
\hline
\end{tabular}




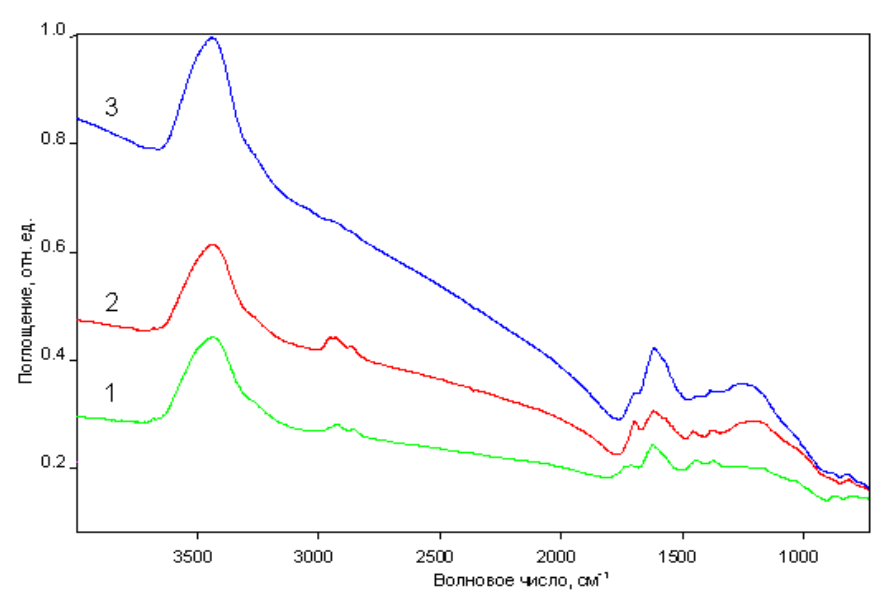

Рис. 4. ИК-спектры образцов: 1 - бетулин при $400{ }^{\circ} \mathrm{C}$ без $\mathrm{KOH} \mathrm{(бетулин-400);}$ 2 - бетулин + КОН (400); 3 - бетулин + КОН (500)

Совокупность п.П., проявляющихся в спектре образца бетулин-400 при 2923 и $2855 \mathrm{~cm}^{-1}$, а также вблизи 1442 и $1373 \mathrm{~cm}^{-1}$, а в спектре бетулин + КОН (400) - при 2960 и $2868 \mathrm{~cm}^{-1}$ и 1457 и $1380 \mathrm{~cm}^{-1}$, указывает соответственно на валентные и деформационные (асимметричные и симметричные) колебания, в первом случае метиленовых $\mathrm{CH}_{2}$, а во втором - метильных $\mathrm{CH}_{3}$-групп [16]. Присутствие $\mathrm{CH}_{2-}$ фрагментов в образце бетулин-400 наиболее вероятно в составе алифатических цепочек, присоединенных к ароматическому кольцу, либо полиэфирных группировок [-( $\left.\left.\mathrm{CH}_{2}\right)-\mathrm{O}-\right]$ [17].

Изменение характера боковых заместителей при пиролизе бетулина в присутствии КОН соотносится с вероятным направлением деполимеризации и распада наиболее длинных $\mathrm{CH}_{2}$-цепочек у продуктов превращения и образованием ароматических фрагментов с более короткими и термически более стойкими метильными группами.

Анализ ИК-спектра образца бетулин + КОН (400) (рис. 4, кривая 2) указывает на увеличение количества различных $\mathrm{C}-\mathrm{O}-\mathrm{H}$ и $-\mathrm{C}-\mathrm{O}-\mathrm{C}$ функциональных групп, в частности фенолов, простых и сложных эфиров, вследствие того, что бетулин способен претерпевать различные окислительные превращения с образованием карбонильных, карбоксильных, эпокси-, гидрокси- и других соединений $[4,11,18]$. Часть спиртовых гидроксилов способны подвергаться глубокому окислению до карбоксилов и альдегидов, что сопровождается снижением интенсивности ОН-групп при $3440 \mathrm{~cm}^{-1}$ и заметным усилением интенсивности п.п. при 1700-1720 $\mathrm{cm}^{-1}$, относящихся к $\mathrm{v}_{\mathrm{C}=\mathrm{O}}$ колебаниям карбонильных групп, в большей степени присутствующих в активированном КОН бетулине.

Возрастание температуры активации бетулина до $500{ }^{\circ} \mathrm{C}$ сопровождается исчезновением п.п. в области 2860-2930 см$^{-1}$ образца бетулин + КОН (500), что свидетельствует о практически полном отщеплении боковых цепей у алкилированных ароматических углеводородов и разрушении всех типов алифатических группировок (рис. 4, кривая 3). Наиболее интенсивное поглощение проявляется при $1617 \mathrm{~cm}^{-1}$ (С-C колебания ароматических колец) и $1466 \mathrm{~cm}^{-1}$ (C-H деформационные колебания в ароматических кольцах), указывающее на усиление ароматизации продукта. Постепенное снижение интенсивности полос в низкочастотной области 870-780 $\mathrm{cm}^{-1}$, отвечающее как неплоским деформационным $\delta \mathrm{C}-\mathrm{H}$ колебаниям связи ароматического типа фрагментов, так и возможным проявлениям деформационных колебаний C-H сопряженных связей у активированных щелочью продуктов, особенно у образца бетулин + КОН (500), может свидетельствовать в пользу снижения количества полиненасыщенных ароматических фрагментов при щелочном активировании [19, 20].

Таким образом, различие исследуемых спектров, характеризующее структурные и термохимические превращения, которые претерпевает бетулин, зависит от направления процесса разложения органического соединения, определяемого в основном температурой и присутствием щелочного активатора.

Влияние бетулина на морфологию углеродных образцов, полученных активированием КОН предварительно карбонизованной при $700{ }^{\circ} \mathrm{C}$ Betula birch (ДБ), было изучено методом сканирующей электронной микроскопии. На микрофотографии модифицированного образца (рис. 5, Б) видна слегка искаженная форма обуглероженных микрофибрилл ДБ и суженные в них входы по сравнению с не модифицированным бетулином образцом ДБ (рис. 5, А). Видимо, обработка карбонизованной древесины березы углеводородным органическим соединением - бетулинолом с большим молекулярным размером (молекулярной массой 442,7) позволяет относительно равномерно распределить продукт термопревращения бетулина по поверхности углеродного носителя в виде полимероподобного слоя. Тем самым создаются условия регулирования пористости реакционноспособной формы промежуточного углеродного композита в условиях последующей активации КОН [8]. 


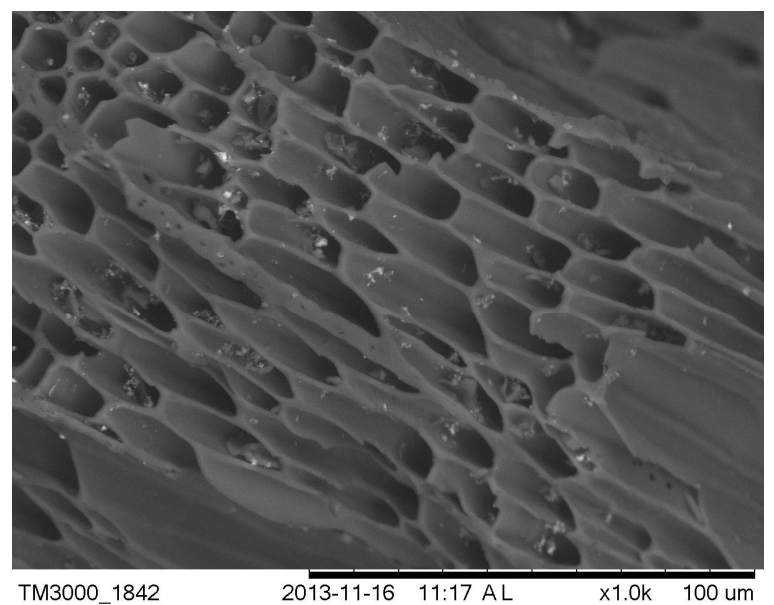

A

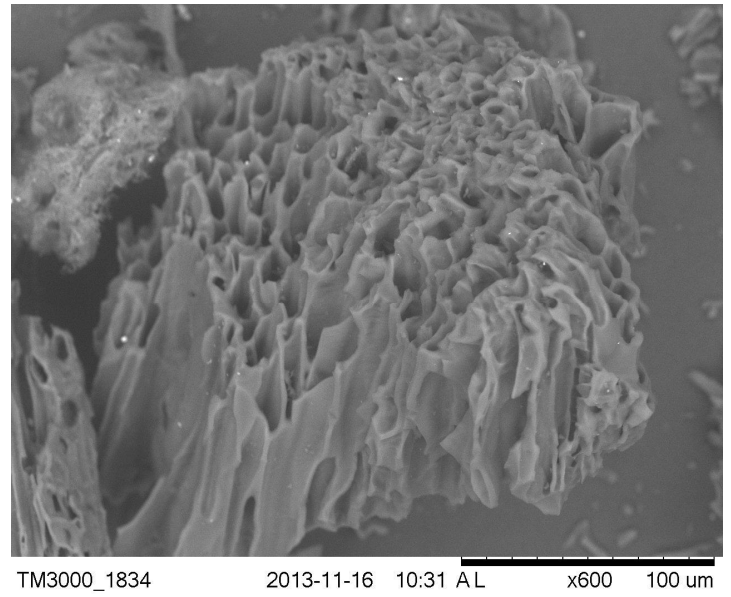

Б

Рис. 5. Микрофотографии активированных КОН образцов ДБ-700: А - без модифицирования (увеличение 1000 раз); Б - после модифицирования бетулином (увеличение 600 раз)

Вероятно, под действием щелочного реагента и вовлечения функциональных группировок бетулина и/или производных окисленных продуктов его термохимических превращений достигаются лучшие условия формирования пористости в реакции с КОН. Активирующее действие КОН эффективно в направлении обоих компонентов композиции бетулин/ДБ, в результате чего обеспечивается получение модифицированных УА с контролируемой способностью для селективной адсорбции и разделения смеси газов $\mathrm{H}_{2}(\mathrm{He})-\mathrm{CH}_{4}[21]$.

\section{Выводы}

Таким образом, методами термогравиметрии, ИК-спектроскопии, сканирующей электронной микроскопии получены данные о функциональном составе и термических свойствах образцов бетулина в условиях его активации КОН в интервале температур 400-800 ㄷ. Выявлено, что присутствие КОН модифицирует поведение бетулина в процессе термодеструкции, способствуя процессам деполимеризации и снижению количества полиненасыщенных фрагментов.

Установлена возможность использования природного модификатора - бетулина для совершенствования микропористой текстуры углеродных носителей при последующей химической активации гидроксидом калия.

Показано, что температурный интервал модифицирующего действия бетулина при Т $400-450{ }^{\circ} \mathrm{C}$ является наиболее подходящим для проявления условий регулирования пористости УМ и улучшения степени разделения модельной смеси метана и гелия.

Установлено, что наибольшее влияние на текстурные и адсорбционные свойства получаемых пористых углеродных материалов оказывает щелочная активация бетулина при $800{ }^{\circ} \mathrm{C}$, способствующая формированию микропористых углеродных материалов с размером пор 1,92 нм и удельной поверхностью микропор $1275 \mathrm{~m}^{2} /$ г.

\section{Список литературы}

1. Кислицын А.Н. Пиролиз древесины: химизм, кинетика, продукты, новые процессы. М., 1990, 312 с.

2. Кислицин А.Н. Экстрактивные вещества бересты: выделение, состав, свойства, применение // Химия древесины. 1994. №3. С. 10-28.

3. Судакова И.Г., Гарынцева Н.В., Кузнецов Б.Н. Изучение процесса выделения субериновых веществ из бересты березовой коры // Химия растительного сырья. 2008. №1. С. 41-44.

4. Шахтшнейдер Т.П., Кузнецова С.А., Михайленко М.А., Маляр Ю.Н., Болдырев В.В. Получение нетоксичных композитов бетулина с поливинилпирролидоном и полиэтиленгликолем // Журнал Сибирского федерального университета. Химия. 2012. Т. 1, №5. С. 52-60.

5. Patočka J. Biologically active pentacyclic triterpenes and their current medicine signification // Journal of Appl. Biomedicine. 2003. Vol. 1. Pp. 7-12. 
6. Babel K., Janasiak D., Jurewicz K. Electrochemical hydrogen storage in activated carbons with different pore structures derived from certain lignocellulose materials // Carbon. 2012. Vol. 50. Pp. 5017-5026.

7. Chihara K., Suzuki M. Control of micropore diffusivities of molecular sieving carbon by deposition of hydrocarbons // Carbon. 1979. Vol. 17. Pp. 339-343.

8. Чесноков Н.В., Микова Н.М., Иванов И.П. Изучение модифицирующего влияния бетулинола на свойства углеродных сорбентов, получаемых из древесины Betula birch // Химия природных соединений. 2014. №3. C. 505-506.

9. Кузнецова С.А., Скворцова Г.П., Маляр Ю.Н., Скурыдина Е.С., Веселова О.Ф. Выделение бетулина из бересты березы и изучение его физико-химических и фармакологических свойств // Химия растительного сырья. 2013. №2. C. 93-100.

10. Микова Н.М., Иванов И.П., Чесноков Н.В., Кузнецов Б.Н. Исследование термощелочной активации лигнина из соломы пшеницы, строения и свойств получаемых активных углей // Химия растительного сырья. 2014. №3. C. 223-231.

11. Толстиков А.Г., Флехтер О.Б., Шульц Э.Э., Балтина Л.А. Бетулин и его производные. Химия и биологическая активность // Химия в интересах устойчивого развития. 2005. №13. С. 1-30.

12. Hayashi J., Kazehaya A., Muroyama K., Watkinson A.P. Preparation of activated carbons from lignin by chemical activation // Carbon. 2000. Vol. 38. Pp. 1873-1878.

13. Lillo-Rodenas M.A., Cazorla-Amoros D., Linares-Solano A. Understanding chemical reactions between carbons and Naoh and KOH: an insight into the chemical activation mechanism// Carbon. 2003. Vol. 41, N2. Pp. 267-275.

14. Wang J., Kaskel S. KOH activation of carbon-based materials for energy storage // J. Mater. Chem. 2012. Vol. 22. Pp. 23710-23725.

15. Микова Н.М., Наймушина Л.В., Чесноков Н.В., Павленко Н.И., Селютин Г.Е., Кржтон А., Кузнецов Б.Н. FTIR- и ЭПР-спектроскопическое изучение процесса пиролиза модифицированной медью целлюлозы // Химия растительного сырья. 2001. №4. С. 53-58.

16. Казицына Л.А., Куплетская Н.Б. Применение УФ-, ИК- и ЯМР-спектроскопии в органической химии : учебное пособие для вузов. М., 1977. 264 с.

17. Дехант И., Данц Р., Киммер В., Шмольке Р. Инфракрасная спектроскопия полимеров. М., 1976, 471 с.

18. Денисенко М.В., Одинокова Л.Э., Денисенко В.А., Уварова Н.И. Окисление бетулина, дигидробетулина и 3р, 28дигидрокси-18-лупена тетраоксидом рутения // Химия природных соединений. 1991. №3. С. 128-129.

19. Michaelian K.H., Friesen W.I. Photoacoustic FT-IR spectra of separated western Canadian coal maserals // Fuel. 1990. Vol. 69. Pp. 1271-1275.

20. Miller J.E., Evans L., Littlewolf A., Trudel D.E. Batch microreactor studies of lignin and lignin model compound depolymerization by bases in alcohol solvens // Fuel. 1999. Vol. 78, N11. Pp. 1363-1366.

21. Патент 2518579 (РФ). Способ получения углеродного адсорбента / Н.М. Микова, И.П. Иванов, Н.В. Чесноков, Б.Н. Кузнецов. 2014.

Поступило в редакциию 19 декабря 2014 2. 
Mikova N.M. ${ }^{{ }^{*},}$, Chesnokov N.V. ${ }^{1,2}$, Mazurova E.V. ${ }^{l}$, Pavlenko N.I. ${ }^{l}$, Ivanchenko N.M. ${ }^{l}$ THE STUDY OF THERMO TRANSFORMATION OF BETULIN IN ALKALINE ACTIVATION ENVIRONMENTS

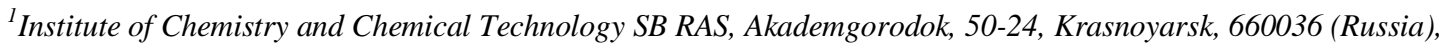

e-mail:nm@icct.ru

${ }^{2}$ Krasnoyarsk scientific centre, Akademgorodok, 50, Krasnoyarsk, 660036 (Russia)

The carbonation of betulin (betulinol) as an individual carbon precursor in the temperature range $400-800{ }^{\circ} \mathrm{C}$ in the presence of $\mathrm{KOH}$ was studied. DTA analysis and IR spectroscopy were used to determine the $\mathrm{KOH}$ influence on major structural changes and chemical composition betulin that it undergoes a temperature of $400-500{ }^{\circ} \mathrm{C}$. By scanning electron microscopy and BET analysis it was shown that at temperatures of $600-800^{\circ} \mathrm{C} \mathrm{KOH}$ promotes the formation of a developed specific surface $\left(\mathrm{S}_{\mathrm{BET}} 1350-2100 \mathrm{~m}^{2} / \mathrm{g}\right)$, and has the greatest influence on the textural and adsorption properties of the resulting porous carbon adsorbents. It has been established that activation of betulin $\mathrm{KOH}$ at $800{ }^{\circ} \mathrm{C}$ is possible to produce microporous carbon materials with a pore size of $1,92 \mathrm{~nm}$ and a micropore specific surface $1275 \mathrm{~m}^{2} / \mathrm{g}$. It was proposed use of betulin as a regulator of the porous carbon carriers from birch wood.

Keywords: betulin, alkaline activation, carbonization, porosity, adsorption properties, surface morphology.

\section{References}

1. Kislitsyn A.N. Piroliz drevesiny: khimizm, kinetika, produkty, novye protsessy. [Pyrolysis of wood: chemistry, kinetics, products, new processes]. Moscow, 1990, 312 p. (in Russ.).

2. Kislitsin A.N. Khimiia drevesiny, 1994, no. 3, pp. 10-28. (in Russ.).

3. Sudakova I.G., Garyntseva N.V., Kuznetsov B.N. Khimiia rastitel'nogo syr'ia, 2008, no. 1, pp. 41-44. (in Russ.).

4. Shakhtshneider T.P., Kuznetsova S.A., Mikhailenko M.A., Maliar Iu.N., Boldyrev V.V. Zhurnal Sibirskogo federal'nogo universiteta. Khimiia, 2012, vol. 1, no. 5, pp. 52-60. (in Russ.).

5. Patočka J. Journal of Appl. Biomedicine, 2003, vol. 1, pp. 7-12.

6. Babel K., Janasiak D., Jurewicz K. Carbon, 2012, vol. 50, pp. 5017-5026.

7. Chihara K., Suzuki M. Carbon, 1979, vol. 17, pp. 339-343.

8. Chesnokov N.V., Mikova N.M., Ivanov I.P. Khimiia prirodnykh soedinenii, 2014, no. 3, pp. 505-506. (in Russ.).

9. Kuznetsova S.A., Skvortsova G.P., Maliar Iu.N., Skurydina E.S., Veselova O.F. Khimiia rastitel'nogo syr'ia, 2013, no. 2, pp. 93-100. (in Russ.).

10. Mikova N.M., Ivanov I.P., Chesnokov N.V., Kuznetsov B.N. Khimiia rastitel'nogo syr'ia, 2014, no. 3, pp. $223-231$. (in Russ.).

11. Tolstikov A.G., Flekhter O.B., Shul'ts E.E., Baltina L.A. Khimiia v interesakh ustoichivogo razvitiia, 2005, no. 13, pp. 1-30. (in Russ.).

12. Hayashi J., Kazehaya A., Muroyama K., Watkinson A.P. Carbon, 2000, vol. 38, pp. 1873-1878.

13. Lillo-Rodenas M.A., Cazorla-Amoros D., Linares-Solano A. Carbon, 2003, vol. 41, no. 2, pp. 267-275.

14. Wang J., Kaskel S. J. Mater. Chem., 2012, vol. 22, pp. 23710-23725.

15. Mikova N.M., Naimushina L.V., Chesnokov N.V., Pavlenko N.I., Seliutin G.E., Krzhton A., Kuznetsov B.N. Khimiia rastitel'nogo syr'ia, 2001, no. 4, pp. 53-58. (in Russ.).

16. Kazitsyna L.A., Kupletskaia N.B. Primenenie UF-, IK- i IaMR-spektroskopii v organicheskoi khimii. [Application of UV, IR and NMR spectroscopy in Organic Chemistry]. Moscow, 1977, 264 p. (in Russ.).

17. Dekhant I., Dants R., Kimmer V., Shmol'ke R. Infrakrasnaia spektroskopiia polimerov. [Infrared spectroscopy of polymers]. Moscow, 1976, 471 p. (in Russ.).

18. Denisenko M.V., Odinokova L.E., Denisenko V.A., Uvarova N.I. Khimiia prirodnykh soedinenii, 1991, no. 3, pp. 128-129. (in Russ.).

19. Michaelian K.H., Friesen W.I. Fuel, 1990, vol. 69, pp. 1271-1275.

20. Miller J.E., Evans L., Littlewolf A., Trudel D.E. Fuel, 1999, vol. 78, no. 11, pp. 1363-1366.

21. Patent 2518579 (RU). 2014. (in Russ.).

Received December 19, 2014

Revised May 19, 2015

\footnotetext{
* Corresponding author.
} 
